\title{
Typology and inequality between island clusters and development areas in Maluku Province
}

\author{
Husen Bahasoan $^{1 *}$; Dedi Budiman Hakim²; Rita Nurmalina²; \\ Eka Intan K Putri ${ }^{2}$ \\ 1) Agriculture and Forestry Faculty, Universitas Iqra Buru Maluku, Indonesia \\ ${ }^{2)}$ Economic and Manajemen Faculty, IPB University Bogor, Indonesia \\ *To whom correspondence should be addressed.E-mail: chen_bhs@yahoo.co.id
}

\begin{abstract}
This study aims to analyze patterns of economic growth and island cluster inequality in Maluku Province during the period 2010-2016. The data in this study are secondary data using quantitative descriptive methods and analytical typology analysis tools and theil index. The results showed that the VIII-IX island cluster which was classified as advanced and fast growing but had a very high inequality compared to other island cluster groups was Tual City, Southeast Maluku Regency and Aru Islands Regency. The division of the Maluku region in the Klassen typology is based on the center of growth with the hinterland area. Southern Maluku as a development area is classified as developed and fast-growing where Tual City is a center of growth but has a very high inequality compared to Maluku in the northern region.
\end{abstract}

Keywords: Growth center, Inequality, Island cluster, Klassen typology

JEL classification: R10, R11

\section{INTRODUCTION}

Regional development in general has the aim to develop the region in a better direction by utilizing the potential of the region to prosper the people in the region. The development of an area requires appropriate policies and strategies and programs. The success of regional development is also determined by the active participation of the community in supporting programs implemented by the government.

To improve the welfare of the community, it is necessary to increase economic growth and equitable distribution of income. This economic growth is measured by Gross Regional Domestic Product (GRDP) and the rate of growth at constant prices (Masli, 2008). The economy of a region is said to have developed growth if the level of economic activity is higher than what was achieved in the previous period. Economic growth is one indicator of people's welfare. Economic growth is an indicator of community welfare in an area (Adisasmita,2005). If an area's economic growth increases, it is hoped that growth can be enjoyed evenly by the entire community.

The development process carried out so far has turned out to be quite complex development problems. Approaches to macroeconomic growth tend to ignore the occurrence of large regional development gaps. Some strategic issues related to interisland inequality problems in Indonesia can be seen from the development of interisland socio-economic conditions in Indonesia according to the Gross Regional 
Domestic Product (GRDP) has not shown a change in the dominance of the Western Region of Indonesia, especially the Java Island to Eastern Indonesia (Figure 1).

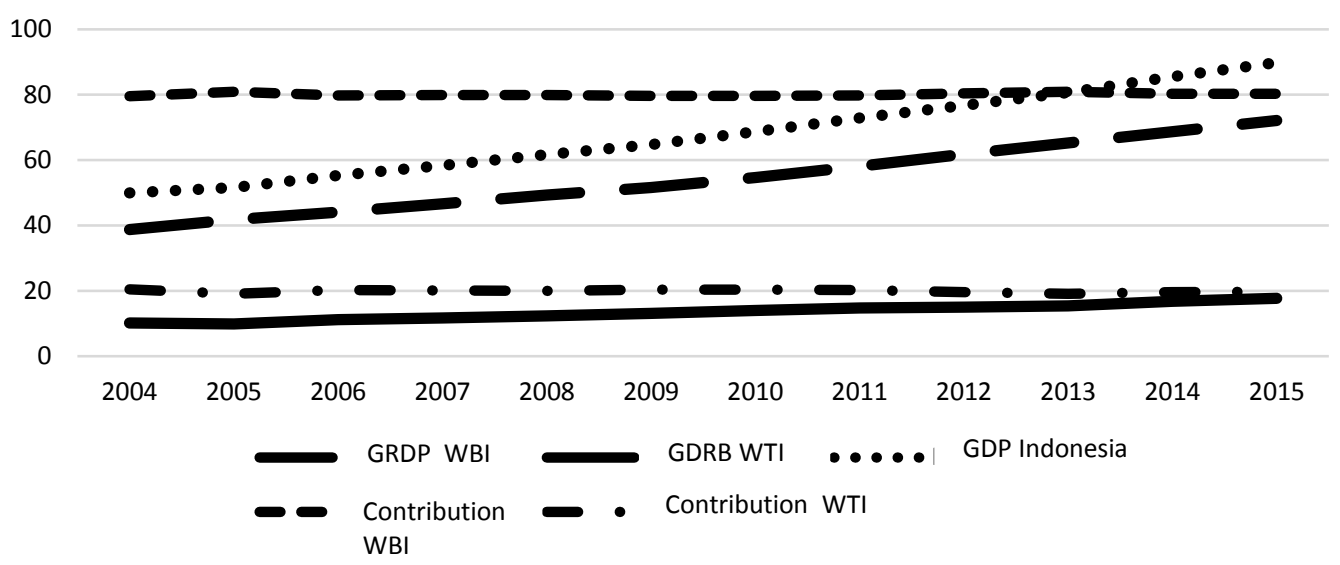

Figure 1. GRDP and contribution of GRDP West Region (WBI) and Eastern Indonesia Region (WTI) in 2004-2015

Inequality in regional development has resulted in stunted regional development due to the low accessibility of economic and social facilities and infrastructure services. The development carried out so far has resulted in regions that are developed, developing and poor. On the other hand development inequality also creates pockets of poverty in remote, isolated, critical and resource-poor areas and is a lagging region that causes disparities between regions. Specifically, disparities between regions in Indonesia occur even though at the same time the provinces are based on data from the BPS-Statistics Indonesia experiencing economic growth. One indicator of the economic growth of the provinces in Indonesia is the increasing Gross Regional Domestic Product (GRDP) of each province, both provinces in Western Indonesia and in Eastern Indonesia. The economic disparity between West and East Indonesia, measured from the GRDP of the 2004-2015 period, has slightly improved (Figure 1). This means that the strategy of forming an economic development zone that aims to encourage the formation of an area that has a role as the prime mover (prime mover) of regional development within a period of almost 20 years was unable to overcome economic disparities between regions.

Sirojuzilam (2005) Inequality that occurs not only to the distribution of community income, but also to interregional development within the territory of a country. Meanwhile, according to Kutscherauer (2010) regional inequality is a difference or dissimilarity of characteristics, phenomena or location conditions and occurs at least between two entities of the regional structure. Inequality must be assessed from several aspects such as social, location conditions, political and administrative, institutional, environmental, public infrastructure and others.

Inequality between regions is a consequence of development and is a stage of change in development itself. Differences in the level of economic progress between regions will cause excessive adverse effects (backwash effects) to dominate the beneficial effects (spread effects) on regional growth, and will lead to an imbalance process (Todaro, 2000). Inequality of economic development between regions according to Sjafrizal (2012) is a common phenomenon that occurs in the process of economic development of a region. This disparity was initially caused by differences in demographic content found in each region. As a result of these differences, the ability of a region to increase economic growth and encourage the development process also 
becomes different. Therefore, it is not surprising that in each region there are usually developed regions and relatively underdeveloped regions.

Maluku Province has 1,340 islands with an area of 712,480 km2, consisting of 92.4 percent of the ocean and 7.6 percent of the land (BPS Maluku, 2017). This large number of islands makes Maluku Province the largest archipelago province in Indonesia, with a characteristic that is small islands. Some small islands scattered and separated by the sea are still isolated/left behind compared to other regions, and are even categorized as 3T Regions (Outermost, Frontier and Disadvantaged). The position of the scattered islands also resulted in a centralized development program in the provincial capital. The implication, the pattern of development will create development gaps between regions and hamper resource mobility because it is not yet supported by an adequate distribution and marketing network. The broad range of control also results in the difficulty of conducting surveillance, evaluation and control of security and order which is quite sensitive among small island communities.

The biggest challenge of development with the condition of scattered territories is to build efficient inter-island connectivity or connectivity in one unified island and sea spatial plan. Development of the Maluku Province region needs to be done by calculating the characteristics of the Maluku Islands region as a unified interconnected region, so that the concept of development policy can be right on target and integrated according to its potential and various obstacles encountered. One of the solutions and development strategies in the archipelago in order to optimize the potential for more prosperous natural and human resources is the development of Island Cluster based.

Island cluster based Maluku Development is a reorientation as well as a review of the development direction of Maluku Province from a sectoral, top down, broken focus and temporary approach to a cross-sectoral, regional, participatory, more focused and sustainable approach. This change in approach is needed considering that Maluku Province has the characteristics of small islands that have limited and limited resource potential, so it is necessary to consolidate regional areas to produce a larger and more powerful and competitive economic scale. The developmental approach which has been sectoral in fact has proceeded according to each direction and the interactions are relatively more mutually negating. Consequently, the use of the budget has become less effective because there are many programs that are misplaced, overlapping, unsustainable and have not yet succeeded in creating competitive products at both the district and provincial levels in Maluku.

The island cluster approach offers a direction of development in Maluku which begins with a common conception and perception that Maluku development must be viewed in a regional or regional perspective, where the development of a sector will be interrelated with other sectors in a regional region to work together, strengthen and synergize for the same goal, namely creating a competitiveness of regional economy based on commodities that are relied upon and superior. This study aims to analyze patterns of economic growth and inequality in Maluku Province (Bappeda Maluku 2014).

\section{METHODS}

\section{Typological analysis}

Klassen typology analysis is used to find a picture of the pattern and structure of economic growth in each region. Regional typology basically divides regions based on two main indicators, namely economic growth and regional per capita income/gross 
regional domestic product on the basis of a region's constant prices. The two main indicators are then divided into two axes: the vertical axis is the average economic growth and the horizontal axis is the average income per capita/gross regional domestic product at constant prices. Klassen's typology model classifies regions into four areas: fast-growing and high-income areas, high-growth but low-income regions, high-income but low-growth regions, and relatively disadvantaged areas (low growth and low income) (Syafrizal 1997; Kuncoro 2012). four:

The analysis used is the regional typology analysis. The criteria used consist of

1. Quadrant I (first), that is, regions that are fast progressing and fast growing are regions that have higher economic growth and income per capita compared to development areas.

2. Quadrant II (second), namely developed but stressed regions are money regions having higher per capita income but lower growth rates compared to development areas.

3. Quadrant III (third), i.e. fast developing regions are regions that have high growth but the level of income per capita is lower than that of development areas.

4. Quadrant IV (fourth) is a region that is relatively underdeveloped is an area that has lower economic growth and income per capita compared to the development area.

Table 1. Typology of regions

\begin{tabular}{ccl}
\hline Growth rate $(\mathrm{r})$ & $\left(\mathbf{y}_{\mathbf{i}}<\mathbf{y}\right)$ & $\left(\mathbf{y}_{\mathbf{i}}>\mathbf{y}\right)$ \\
\hline$\left(\mathrm{r}_{\mathrm{i}}>\mathrm{r}\right)$ & Low income, but high growth (III) & High income, high growth (I) \\
$\left(\mathrm{r}_{\mathrm{i}}<\mathrm{r}\right)$ & Low income and low growth (IV) & High income, but low growth (II)
\end{tabular}

Source: Kuncoro (2012)

Note: $r=$ average economic growth in the development area

$y=$ average GRDP per capita of development area

ri $=$ observed regency/city economic growth

yi $=$ regency/city per capita GRDP observed

Regional typology, will be done every year to see the development of each regency/city in one development area.

\section{Regional inequality analysis}

The analysis used to look at development inequality is Theill Entropy Index Analysis which is the application of information theory concepts in measuring inequality about per capita income and income inequality. Theil's index formula (Ying, 2000 in Kuncoro, 2012) is as follows:

$$
\mathrm{T}=\sum\left(\frac{\mathrm{y}_{\mathrm{i}}}{\mathrm{Y}}\right) \mathrm{X} \log \left(\frac{\mathrm{y}_{\mathrm{i}}}{\mathrm{Y}} / \frac{\mathrm{x}_{\mathrm{i}}}{\mathrm{X}}\right)
$$

Note : $\mathrm{T}=$ Total Dispparity (Theil Index) of Development Area

$\mathrm{y}_{\mathrm{i}}=$ Regency/city GRDP-i in the Development Area

$\mathrm{X}_{\mathrm{i}}=$ Number of residents of the regency/city-i in the Development Area.

$\mathrm{Y}=$ GRDP Development area

$\mathrm{X}=$ Population Number of the development area 


\section{RESULTS AND DISCUSSION}

\section{Klassen typology}

Klassen's typological analysis is divided into three based on the study area: district/ city, island cluster and region. To classify regions based on these criteria, the data presented are the development of economic growth rates and per capita income in 2010-2016.

Maluku Province as an archipelago, for that the approach initiated by the government is the development approach which is based on the Island cluster concept. Based on Maluku Province Regional Regulation Number 16 of 2013 concerning Spatial Planning for Maluku Province in 2013-2033, there are 12 Island Clusters in Maluku Province, namely: Cluster I Island covers the territory of Buru Island; The Island II cluster includes the West Seram Region; The Island III cluster includes the North Seram Region; The Island IV cluster covers the East Seram Region; The V Island group covers the South Seram Region; The Island VI cluster includes the Banda Islands Region, Teon Island, Nila Island and Serua Island; The VII Island cluster covers the Ambon Island Region and Lease Islands; The VIII Island cluster includes the Kei Islands Region; The IX Island cluster includes the Aru Islands Region; The X Island cluster includes the Tanimbar Islands Region; The XI Island cluster includes the Babar, Leti, Moa, Lakor and Damer Islands Regions; and the XII Island Cluster covering the South and Region of Wetar Island (Bappeda Maluku 2014).

Table 2. Average economic growth rate and revenue per capita of regencies/cities in Maluku Province 2010-2016

\begin{tabular}{lcc}
\hline \multicolumn{1}{c}{ Regency/City } & Growth Rate (\%) & Income Per Capita (Rp) \\
\hline Ambon & 6.66 & $19,118,975$ \\
Tual & 6.19 & $16,614,286$ \\
Central Maluku (Malteng) & 5.62 & $11,451,414$ \\
Buru & 5.37 & $9,310,228$ \\
South Buru (Bursel) & 5.55 & $10,996,096$ \\
West Seram (SBB) & 5.51 & $8,434,143$ \\
East Seram (SBT) & 5.71 & $15,011,143$ \\
Aru Islands & 6.01 & $17,754,286$ \\
Southeast Maluku (Malra) & 6.03 & $13,938,571$ \\
West Southeast Maluku (MTB) & 6.09 & $10,880,000$ \\
Southwest Maluku (MBD) & 6.50 & $10,537,778$ \\
\hline Maluku & $\mathbf{5 . 9 1}$ & $\mathbf{1 3 , 0 9 5 , 1 7 5}$ \\
\hline
\end{tabular}

The island cluster concept is carried out by developing growth centers as public service centers, trade centers and the flow of goods and services. This island cluster approach is considered more appropriate for regions with archipelagic geographical conditions by dividing or grouping islands into several groups of islands to be made central (cluster centers) that have relatively the same characteristics and proximity. In analyzing the typology of Klassen based on the island group approach, the study was divided into 4 (four) groups of island cluster namely (1) group I island cluster , (2) group II-VII island cluster, (3) group VIII-IX island cluster and (4) group X-XII island cluster.

Table 3 shows the group of island cluster I the average GRDP per capita and economic growth is lower than the GRDP per capita and growth in Maluku. The average GRDP per capita clusters group II-VII is higher than the GRDP per capita in 
Maluku while the average economic growth is lower than Maluku. The island cluster VII-IX average per capita GRDP and economic growth is higher than the per capita GRDP and Maluku economic growth. The island cluster X-XII the average GRDP per capita is lower than the average GRDP per capita in Maluku, while the average economic growth is higher than the average growth of the Maluku economy. Regions with the same type, limiting one to another or there is a grouping pattern based on fastgrowing and advanced/rich types and does not cover regency/cities with advanced and fast-growing categories klassen typology in quadrant $\mathrm{I}$ is. candidate for growth pole (Wibisono, 2015).

Typology of class groups of island cluster in Figure, the category of developed and fast-growing regions in group VIII-IX island cluster. This island cluster has higher economic growth and income per capita compared to the development area (province). Tual City is the administrative capital and is the parent of the newly established region of Southeast Maluku Regency and Aru Islands Regency. The high growth rate is because Tual City is central to Southeast Maluku Regency and Aru Islands Regency in the transportation route, especially sea transportation. Large cargo ships that stop at the port of Tual so that the flow of goods and passengers, access to facilities and infrastructure are very adequate. The quality of human resources is sufficient by increasing community productivity. The increase in per capita income for Tual City, Southeast Maluku Regency and Aru Islands Regency was the biggest contribution to the fisheries, services, industry and transportation sectors. The largest seaweed industry in Maluku is in the City of Tual and Southeast Maluku, while the fish and pearl processing industry is in the Aru Islands Regency. Besides that the regional and cultural characteristics between Tual City, Southeast Maluku Regency and Aru Islands are the same.

Table 3. Klassen typology by island cluster group in Maluku Province

\begin{tabular}{lcc}
\hline \multicolumn{1}{c}{ Island Cluster } & GRDP per capita & Economic Growth \\
\hline Cluster I: & & \\
Buru Regency & $9,310,228$ & 5.37 \\
South Buru Regency (Bursel) & $10,996,096$ & 5.55 \\
\hline Average & $10,153,162$ & 5.56 \\
\hline Cluster II-VII: & & \\
Ambon City & $19,118,975$ & 6.66 \\
Centra Maluku Regency (Malteng) & $11,451,414$ & 5.62 \\
West Seram Regency (SBB) & $8,434,143$ & 5.51 \\
East Seram Regency (SBT) & $15,011,143$ & 5.71 \\
\hline Average & $13,503,919$ & 5.88 \\
\hline Cluster VIII-IX: & & \\
Tual City & $16,614,286$ & 6.19 \\
Southeast Maluku Regency (Malra) & $13,938,571$ & 6.03 \\
Aru Islands Regency & $17,754,286$ & 6.01 \\
\hline Average & $16,102,381$ & 6.07 \\
\hline Cluster X-XII: & & \\
West Southeast Maluku Regency (MTB) & $10,880,000$ & 6.09 \\
Southwest Maluku Regency (MBD) & $10,537,778$ & 6.50 \\
\hline Average & $10,708,889$ & 6.29 \\
\hline Maluku & $13,095,175$ & 5.91 \\
\hline
\end{tabular}


The developed but depressed regions (Figure 2) in the island cluster II-VII. In the category of Ambon City cluster groups have a high level of income compared to the development area but the growth rate is lower. Ambon City is the Capital of Maluku Province, as a transportation center for all regencies/cities in Maluku. The transportation, service, trade and accommodation sectors contributed to per capita income while Central Maluku Regency, East Seram Regency and West Seram Regency agriculture sector contributed more than other sectors. High unemployment and limited availability of labor and urbanization of the population from rural to urban areas. Slow economic growth in the long run will be able to catch up with rapid and advanced economic growth. Increased unemployment can lead to higher poverty in society. Island Cluster X-XII is the same regency before it was divided, West Southeast Maluku Regency is the main district. The economic growth of this group is higher than the development area (province) with the development of such a rapid development, increased population productivity and good management of natural resources will significantly increase income.

The island cluster I are categorized as regions that are relatively underdeveloped (Figure 2). Buru Regency is the parent district of South Buru Regency which is an area with inadequate facilities and infrastructure and limited transportation, decreased quality of human resources and management of natural resources that is less than optimal so that the increase in regional income is also reduced. Typology of regencies/cities that are included in developed and rapidly developing regions are regions that have high per capita income and absorption of labor and have adequate infrastructure (Pratiwi, 2016).

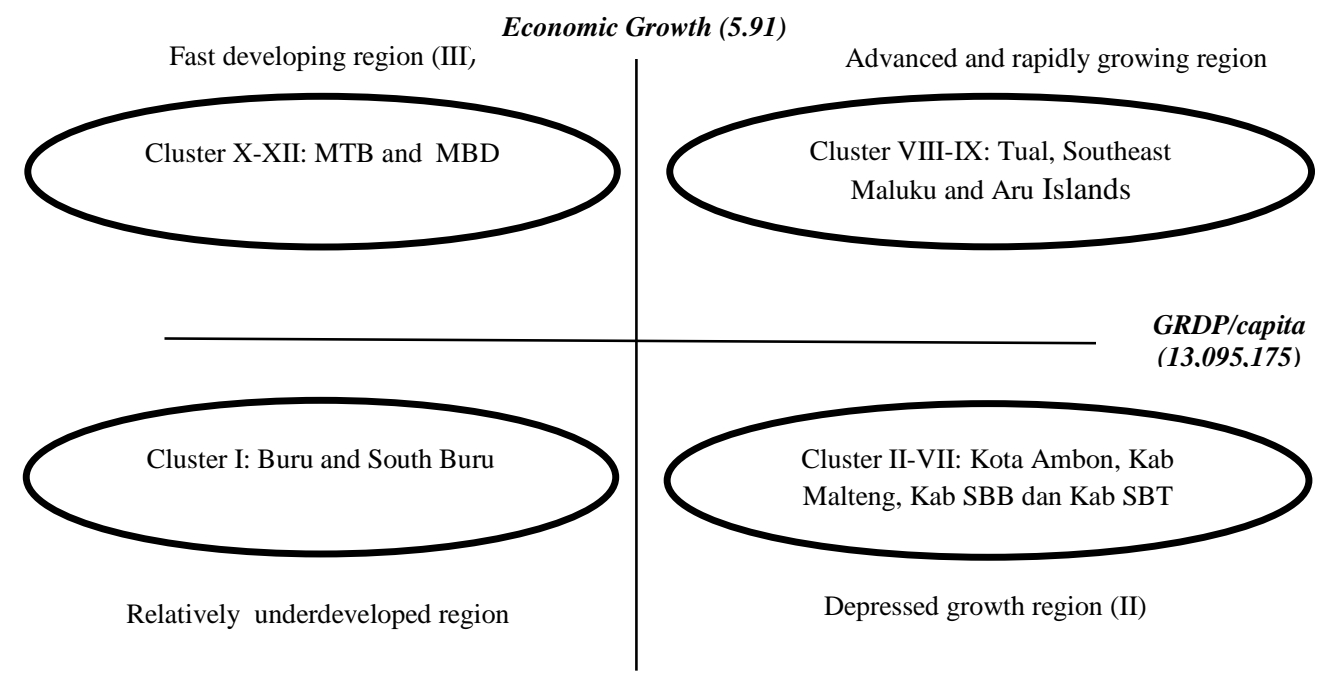

Figure 2 Klassen typology based on island cluster

Maluku province consisting of 2 cities and 9 regencies, the division of Maluku in the Klassen typology is based on growth centers with hinterland areas. Ambon City and Tual City are the centers of growth in Maluku, while other regency are supporting regions (hinterland). The division of territory based on North Maluku covers Ambon City, Malteng Regency, SBB Regency, SBT Regency, Buru Regency and Bursel Regency, while South Maluku Region covers Tual City, Malra Regency, Aru Islands Regency, MTB Regency and MBD Regency. 
Table 4 Klassen typology based on region division

\begin{tabular}{lcc}
\hline \multicolumn{1}{c}{ Region } & GRDP Per Capita & Economic Growth \\
\hline North Maluku Region: & & \\
1. Ambon City & $19,118,975$ & 6.66 \\
2. Malteng Regency & $11,451,414$ & 5.62 \\
3. SBB Regency & $8,434,143$ & 5.51 \\
4. SBT Regency & $15,011,143$ & 5.71 \\
5. Buru Regency & $9,310,228$ & 5.37 \\
6. Bursel Regency & $10,996,096$ & 5.55 \\
\hline Average & $12,387,000$ & 5.73 \\
\hline South Maluku Region: & & \\
1. Tual City & $16,614,286$ & 6.19 \\
2. Malra Regency & $17,754,286$ & 6.03 \\
3. Aru Islands Regency & $13,938,571$ & 6.01 \\
4. MTB Regency & $10,880,000$ & 6.09 \\
5. MBD Regency & $10,537,778$ & 6.50 \\
\hline Average & $13,944,984$ & 6.16 \\
\hline Maluku & $13,095,175$ & 5.91 \\
\hline
\end{tabular}

Table 4 shows the typology of Northern Region Maluku for an average economic growth of 5.73 and per capita GRDP 12,387,000 lower than Maluku Province while Southern Region Maluku averaged 6.16 percent economic growth and GRDP per capita 13,944,984 higher than Maluku Province with economic growth of 5.91 percent and GRDP per capita 13,095,175. South Maluku, which consists of Tual City, Malra Regency, Aru Islands Regency, MTB Regency and MBD Regency are included in the category of developed and fast growing regions because this region has higher economic growth and GDP per capita than Maluku Province. For North Maluku, which consists of Ambon City, Malteng Regency, SBB Regency, SBB Regency, Buru Regency and Bursel Regency are categorized as relatively underdeveloped because this region has lower economic growth and GRDP per capita compared to Maluku Province (Figure 3). The regional approach in Indonesia based on typology Klassen Maluku Province is a developed province but has been depressed in recent years experiencing relatively small growth, due to depressed main activities of the province concerned (Sari, 2013). There is no dominant development area or underdeveloped area and developing area. In general all development areas are developing regions but are depressed and developing rapidly (Raafi'i, 2018).

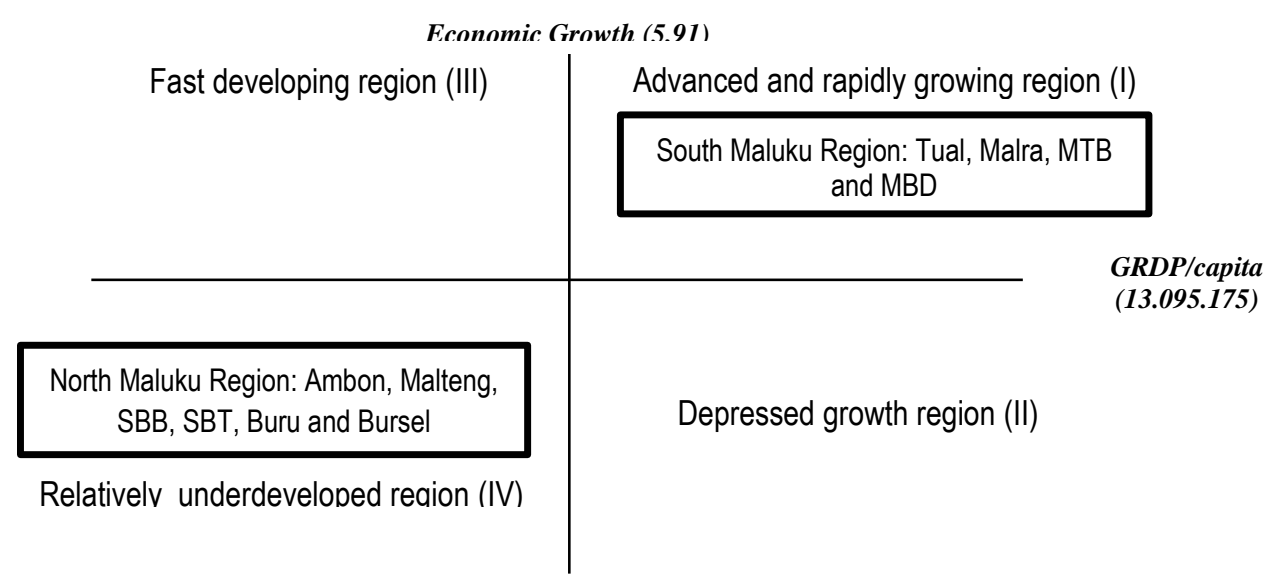

Figure 3 Klassen typology by development area 


\section{Inequality analysis in Maluku}

The difference in GRDP per capita between regencies/cities in Maluku Province provides an overview of the conditions and development in regencies/cities in Maluku Province. The level of income inequality between regencies/cities in Maluku Province is calculated using theil entropy index. The greater Entrophi Theil index means that it shows greater inequality, if the index gets smaller the more even income distribution. Theil Entropy Index can be decomposed/divided into within gaps and between. This inequity (whitin) is based on the classification of the Klassen typology with the island cluster approach in Maluku Province into 4 groups according to growth and GRDP per capita, namely (1) island cluster I, (2) island cluster II-VII, (3) cluster cluster VII-IX and (4) island cluster X-XII.

Theil index values in Table 5 indicate inequality in Maluku Province. Inequality in the 2010-2016 period for theil index between island clusters tends to be stable and the value is 1.08 while theil index in the island cluster inequality that occurs is also stable in 2010-2016. Island cluster I, island cluster II-VII and X-XII island cluster have an average gap of 0.8 , while the island cluster VIII-IX have an inequality value of 1.5 . The gap between island cluster is the use of GRDP by providing a high gap because not all regions have natural resources and make a large enough contribution to district GRDP. Government expenditure does not affect inequality but investment is very influential on regional inequality (Barika, 2012). The increase in economic growth is accompanied by an increase in inequality because the majority of the population are farmers, the government must prioritize improving the quality of agricultural human resources to achieve high agricultural productivity and efficiency to improve the economy (Maulidiyah, 2014).

Table 5. Theil Entrophi Index by island cluster 2010-2016

\begin{tabular}{cccccc}
\hline \multirow{2}{*}{ Tahun } & \multirow{2}{*}{\begin{tabular}{c} 
Theil \\
\cline { 3 - 6 }
\end{tabular}} & $\begin{array}{c}\text { Island } \\
\text { Between }\end{array}$ & $\begin{array}{c}\text { Island Cluster I } \\
\text { II-VII }\end{array}$ & $\begin{array}{c}\text { Island Cluster } \\
\text { VIII-IX }\end{array}$ & $\begin{array}{c}\text { Island Cluster } \\
\text { X-XII }\end{array}$ \\
\hline 2010 & 1,0944 & 0,9464 & 1,1324 & 1,3437 & 0,7926 \\
2011 & 1,0858 & 0,8968 & 0,8760 & 1,6451 & 0,8554 \\
2012 & 1,0833 & 0,8862 & 0,8579 & 1,6555 & 0,8728 \\
2013 & 1,0805 & 0,8703 & 0,8344 & 1,3054 & 0,8974 \\
2014 & 1,0877 & 0,8590 & 0,8296 & 1,6717 & 0,9565 \\
2015 & 1,0849 & 0,8550 & 0,8303 & 1,6689 & 0,9481 \\
2016 & 1,0363 & 0,8480 & 0,6905 & 1,6666 & 0,9710 \\
\hline
\end{tabular}

Inequalities between the development areas of the North Maluku Region and South Maluku Region are presented in Table 6.

Table 6. Inequalities between development areas in Maluku in 2010-2016

\begin{tabular}{lccc}
\hline \multirow{2}{*}{ Tahun } & \multirow{2}{*}{ Theil } & \multicolumn{2}{c}{ Theil Within } \\
\cline { 3 - 4 } & Between & North Region Maluku & South Region Maluku \\
& & & 1,0704 \\
2010 & 1,0944 & 0,8830 & 1,3293 \\
2011 & 1,0858 & 0,8673 & 1,3424 \\
2012 & 1,0833 & 0,8643 & 1,3615 \\
2013 & 1,0805 & 0,8394 & 1,3856 \\
2014 & 1,0877 & 0,8385 & 1,3806 \\
2015 & 1,0849 & 0,7430 & 1,3883 \\
2016 & 1,0363 & & \\
\hline
\end{tabular}


Inequality between development areas in Table 6, it can be seen from the contribution to the Theil value between Northern Region Maluku and Southern Region Maluku that are very lame. Inequality in the development area must be directed to reduce so as not to cause problems in the erosion of resources between districts in the development area. Scouring can occur in natural resources and human resources. Reccomendations Inequality of income by many factors such as the unfair allocation of central and regional government expenditure, expenditure for capital expenditure is still very low, the number of regional heads caught in legal problems (Agusalim, 2016). As a result of crushing is the inability of an area to be able to develop better because of the abandonment of quality human resources and poor value-added natural resource management. The role of local government is needed to move the potential sector as a driver of the regional economy (Ardila, 2012).

\section{CONCLUSIONS AND RECCOMENDATIONS}

\section{Conclusion}

Based on the identification of typology of island cluster, Tual City, Southeast Maluku Regency and Aru Islands Regency (island cluster VIII-IX) are fast-growing and advanced regions because Tual City is the center of growth and the effects of development abundance from 2010 to 2016 which makes the cluster this island is more developed and developing rapidly, while island cluster II-VII are developed but depressed regionsan increase in community productivity but a decrease in the quality of human resources causes an increase in the number of unemployed which is compounded by fewer jobs, island cluster XI-XII are in the fast developing regions due to increased population productivity and natural resource management has not been managed properly and the lack of human resources and island cluster I are in disadvantaged areas due to the lack of regional facilities and infrastructure, especially transportation, decreased quality of human resources and management of natural resources that are less than optimal. Klassen's typology is based on the area of development of growth centers with hinterland areas. The South Maluku Region (Tual City, Southeast Maluku Regency, Aru Islands Regency, West Southeast Maluku Regency and Southwest Maluku Regency) is a fast-growing and advanced region while the North Maluku Region (Ambon City, Central Maluku Regency, West Seram Regency, Regency Eastern Seram, Buru Regency and South Buru Regency) are areas that are lagging behind.

Inequality in the period 2010-2016 for theil index between island clusters tends to be stable while theil index in the island clusters is high inequality 1.5 in the island cluster VIII-IX compared to the island cluster the other is lower with a 0.8 of 0 . The gap between island cluster is the use of GRDP by providing a high gap because not all regions have natural resources and make a large enough contribution to district GRDP. Inequality between development regions can be seen from the contribution to the Theil value between Maluku North Region and Maluku South Region very lame. Inequality in the development area must be directed to reduce so as not to cause problems in the erosion of resources between districts in the development area. 


\section{Recommendations}

To strengthen linkages between island clusters, a program of cooperation between island cluster can be developed based on sector linkages. Increasing accessibility between island clusters, especially for disadvantaged and border areas through increasing the provision of transportation infrastructure, providing pioneering modes of transportation in areas that cannot be reached by public transportation, and developing transportation cooperation. Efforts that can be made so that inequality between development areas can continue to be stable or decrease is an increase in cooperation so that a balanced economic increase occurs.

\section{REFERENCES}

Adisasmita, R. (2005). Dasar-dasar Ekonomi Wilayah. Yogyakarta: Graha Ilmu.

Agusalim, L. (2016). Pertumbuhan Ekonomi, Ketimpangan Pendapatan dan Desentralisasi di Indonesia. Kinerja, 20 (1), 53-68.

Ardila R. (2012). Analisis Pengembangan Pusat Pertumbuhan Ekonomi di Kabupaten Banjarnegara. Economics Development Analysis Journal (EDAJ), 1(2), 1-9.

Badan Perencanaan Pembangunan Daerah Maluku. (2014). Laporan Akhir Kajian Arah Pengembangan Pembangunan Maluku Berbasis Gugus Pulau. Ambon: Bappeda Maluku.

Badan Pusat Statistik Maluku. (2017). Provinsi Maluku Dalam Angka 2017. Ambon: BPS Maluku.

Barika. (2012). Analisis Ketimpangan Pembangunan Wilayah Kabupaten/Kota di Provinsi Bengkulu Tahun 2005-2009. Jurnal Ekonomi dan Perencanaan Pembangunan, 4 (08),1-11.

Kutscherauer, Al. (2010). Regional Disparities In Regional Development of the Czech Republic. Ostrava: Universitas Teknik Ostrava.

Kuncoro. (2012). Perencanaan Daerah: Bagaimana Membangun Ekonomi Lokal, Kota dan Kawasan. Jakarta: Salemba Empat.

Masli, L. (2008). Analisis Faktor-faktor Yang Mempengaruhi Pertumbuhan Ekonomi dan Ketimpangan Regional Antar Kabupaten/Kota di Provinsi Jawa Barat. Available at: http://www.stanim.ac.id.

Mauliddiyah,A.(2014). Analisis Disparitas Regional dan Pertumbuhan Ekonomi (Studi Kasus di Kota Batu Tahun 2002-2012). Jurnal Ekonomi dan Studi Pembangunan (JESP), 6(2), 156-163.

Pratiwi, M.C.Y. \& Kuncoro, M. (2016). Analisis Pusat Pertumbuhan dan Autokorelasi Spasial di Kalimantan: Studi Empiris di 55 Kabupaten/Kota, 200-2012. Jurnal Ekonomi dan Pembangunan Indonesia, 16 (2), 81-104.

Raafi'i, A., D.B. Hakim,, \& E.I.K. Putri. (2018). Ketimpangan Pembangunan Antarwilayah Pengembangan di Provinsi Papua Barat. Journal of Regional and Rural Development Planning, 2 (3), 244-257.

Sari, Norma R., Arif, P. (2013). Analisis Pertumbuhan Ekonomi dan Ketimpangan Pendapatan Antar Provinsi di Indonesis Tahun 2004-2010. Diponegoro Journal of Economic, 1 (3), 1-15.

Sirojuzilam. (2005). Beberapa Aspek Pembangunan Regional. Bandung: Ikatan Sarjana Ekonomi Indonesia. 
Sjafrizal. (2012). Ekonomi Wilayah dan Perkotaan. Jakarta: Rajawali Press.

Todaro. (2000). Pembangunan Ekonomi di Dunia Ketiga. Surabaya: Erlangga.

Wibisono, P. \& Kuncoro, M. (2015). Efek Limpahan Pertumbuhan Antar Kabupaten/Kota di Provinsi Jawa Timur Tahun 2001-2013. Jurnal Ekonomi dan Pembangunan Indonesia, 16 (1), 31-46. 